\title{
"SISTEM INFORMASI PENJUALAN ACCESSORIES HANDPHONE DAN PENGHARUM RUANGAN BERBASIS WEB PADA TOKO BERKAH SUKSES COMPUTINDO PRINGSEWU".
}

\author{
Rima Mawarni ${ }^{1}$, Dwi Marisa Efendi ${ }^{2}$, David Nurhidayatullah ${ }^{\mathbf{3}}$ \\ Program Studi Sistem Informasi \\ STMIK DIAN CIPTA CENDIKIA KOTABUMI \\ Jl.Negara No. 03 Candimas Kotabumi- Lampung Utara \\ Email: Rima@dcc.ac.Id, Dwimarisa@dcc.ac.id,dafid@gmail.com
}

\begin{abstract}
ABSTRAK
Dengan kemajuan teknologi terutama pada bidang teknologi informasi, website adalah salah satu media yang tepat untuk memberikan layanan informasi. Dengan membangun sebuah perangkat lunak layanan informasi berbasis media website, tentunya segala layanan informasi yang hendak diberikan terhadap masyarakat ataupun sekedar mengenalkan identitas perusahaan itu sendiri dapat menggunakan media website tanpa adanya keterbatasan ruang informasi karena website bersifat dinamis sehingga dapat berubah-ubah isi website itu sendiri sesuai dengan kebutuhan.

Untuk mengatasi permasalahan yang ada, penulis membuat sebuah rancangan sistem baru yang dituangkan dalam bentuk rancangan Extreme Programming, Rancangan $U M L$, dan pembuatan program sistem informasi yang menggunakan bahasa pemograman berbasis Web.

Dengan dibuatnya sistem baru yang didukung dengan program berbasis Web untuk pengolahan data penjualan accessories handphone dan pengharum ruangan diharapkan nantinya alur sistem yang berjalan dapat terhindar dari kesalahan dan memudahkan pengelola atau pemilik toko dalam bertransaksi secara online. Program Sistem Informasi Berbasis Web ini dapat digunakan sebagai penentu pengambilan kebijakan tentang penjualan yang sudah banyak sekali produk dan pesaing dalam bertransaksi jual beli secara online.
\end{abstract}

Kata Kunci :Accessories, Extreme Programming, Unified Modelling Language 


\begin{abstract}
With the progression of the technology especially on the field of information technology, website also pay attention to is one of the media be the perfect moment to provide the information. By working to build a software to of services information media based website also pay attention to, obviously this will only happen all of services information who was about to be rendered against residents and much more than rattle off introduce the identity of nts an nts spokesperson said yourselves bear me uses the media owned enterprises without any website also pay attention to having only a limited number the same type of chambers of information because nature of the decrees issued website also pay attention to dynamic so that it can be changed - authentication is required to change the content of the the website itself in accordance with theirneeds.

To overcome the existing problems, writer make a design the new system that listed in the form of design extreme programming, uml design, and in the preparation of system programs information who uses language programming web-based.

With he made the new system supported by program web-based to data processing sales accessories cell phones and pengharum room expected later on a groove system that runs can be spared from error and facilitate the shop owners transaction online. System programs information web-based it may be used as the best the the policy on sales is plenty products and competitors transaction trading online .
\end{abstract}

Keywords: accessories, extreme programming, unified modelling language 


\section{Latar Belakang}

Teknologi informasi merupakan salah satu bidang yang berkembang pesat dibandingkan dengan bidang-bidang yang lainnya. Selain itu, di zaman sekarang teknologi informasi memberikan pengaruh yang sangat besar terhadap berbagai aspek kehidupan masyarakat. Banyaknya jenis usaha yang berkembang pada saat ini yang membutuhkan aplikasi penunjang yang akan mempermudah dalam pengembangan usahanya. Salah satu cara yang banyak digunakan oleh para usahawan saat ini adalah dengan menggunakan fasilitas internet untuk mempromosikan barang dagangan usahanya.

Penjualan aksesoris merupakan salah satu perdagangan yang sangat banyak diminati pada saat ini. Setiap hari, selalu ada orang-orang yang berdatangan untuk membeli accessories handphone sesuai keinginan mereka dengan mengikuti perkembangan zaman accessories handphone yang begitu berkembang dengan cepat seperti yang terjadi pada Accessories Handphone Berkah Sukses Computindo Pringsewu ini.

Toko Accessories Handphone dan Pengharum Ruangan Berkah Sukses Computindo Pringsewu adalah salah satu toko yang sedang berkembang di Pringsewu, toko ini menjual berbagai perlengkapan accessories handphone dan pengharum ruangan pada zaman sekarang seperti tongsis, kabel data, power bank, pelindung kabel, super wide, fish eye, lampu led sikat dan accessories lainnya serta pengharum ruangan yang beraneka macam aroma. Namun sistem penjualan pada Accessories Handphone dan Pengharum Ruangan Berkah Sukses Computindo Pringsewu sampai saat sekarang ini masih menggunakan sistem manual, dimana sistem ini sudah sangat tidak efisien lagi dipakai pada era sekarang ini yang menuntut segala sesuatunya untuk serba praktis dan cepat.

Berdasarkan uraian tersebut untuk meningkatkan kinerja tempat usaha dan memperkenalkan informasi tentang produk-produk yang dijual kepada masyarakat atau calon pelanggan diperlukan suatu media penyampaian informasi. Berdasarkan kondisi tersebut maka penulis ingin membuat sebuah tugas akhir yang mengangkat judul : "Sistem Informasi Penjualan Accessories Handphone dan Pengharum Ruangan Berbasis Web Pada Toko Berkah Sukses Computindo Pringsewu"..

\section{Metodologi Penelitian}

3.4 Metode Pengembangan Sistem

Dalam penelitian ini, peneliti menggunakan metode pengembangan sistem eXtreme Programming (XP). Dimana metode pengembangan sistem ini memiliki 13 aspek dasar yaitu : 


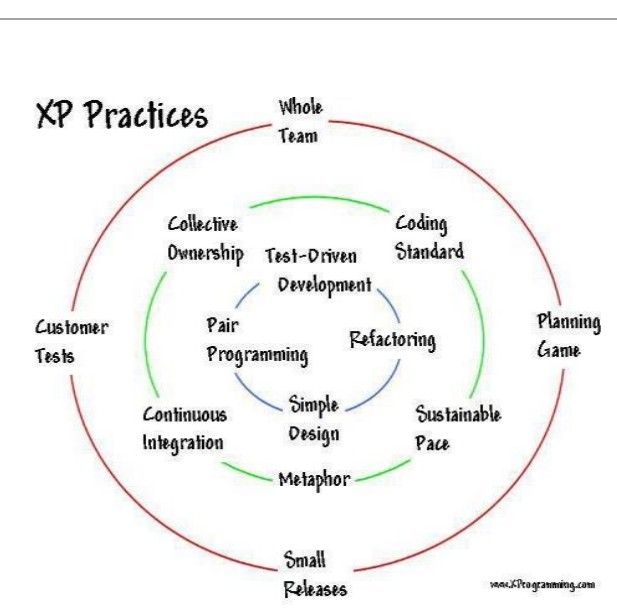

Gambar: 3.4 Aspek Dasar Extreme Progamming

Dengan menggunakan Metode pengembangan sistem Extreme Programming, maka akan mempermudah peneliti dalam pembuatan website. Dan ketika pembuatan web sudah sampai pada tahap pengembangan, tetapi ada yang akan diperbaiki pada saat perancangan, maka tahap perancangan bisa kembali pada tahapan sebelumnya, dan bisa dilanjutkan kembali. Berikut adalah penjelasan tentang Metode Pengembangan Sistem Extreme Programming yang peneliti gunakan untu membuat Sistem Informasi Penjualan Accessories Handphone Dan Pengharum Ruangan Berbasis Web Pada Toko Berkah Sukses Computindo.

\section{Whole Team}

Tahapan ini adalah tahapan dimana yang berperan dalam pembuatan website sistem informasi penjualan ini adalah pembuat program, dosen pembimbing, dan pemilik toko Berkah Sukses Computindo. Jika kerjasama terjalin dengan baik maka akan mempermudah pembuatan program.

\section{Planning Game}

Tahap ini adalah tahap perencanaan dari website penjualan accessories handphone dan pengharum ruangan, dimana pada tahapan perencanaan awalnya adalah menentukan bagian - bagian apa saja yang akan dimasukkan dalam website. Dalam website penjualan accessories handphone dan pengharum ruangan ini adalah petugas atau admin, calon pembeli atau pembeli, kategori barang, dan bank pembayaran.

\section{Small Releases}

Tahapan small releases adalah tahapan pembuatan alur sistem dan alur aplikasi. Pada tahapan pembuatan alur sistem ini dilakukan dengan menganalisa alur sistem yang sedang berjalan, kemudian melakukan perbaikan terhadap sistem yang sedang berjalan pada toko Berkah Sukses Computindo. Dalam tahapan ini akan dilakukan pembuatan UML (Unified Modeling Language) yaitu Class Diagram, Use Case Diagram, dan Sequence Diagram. Ini nantinya bertujuan untuk mempermudah pembuatan website penjualan pada toko Berkah Sukses Computindo.

\section{Metaphor}

Tahapan ini adalah tahapan yang menjelaskan tentang arsitektur website dimana pada tahapan ini penyusunan dan penentuan standarisasi folder dalam website 
yang akan dibuat supaya

memudahkan penulis untuk membuat aplikasi sistem informasi penjualan berbasis web pada toko Berkah Sukses Computindo.

\section{Simple Design}

Tahapan ini penulis mulai membuat desain input dan output website sistem informasi penjualan pada toko Berkah Sukses Computindo.

\section{Refactoring}

Tahapan ini adalah penghapusan duplikasi dari code yang telah dibuat. Disamping itu, proses refactoring didukung dengan pengujian yang komprehensif untuk memastikan bahwa desain yang dibuat penulis berkembang dan tidak ada yang rusak atau eror saat apilkasi di jalankan.

\section{Test-Driven Development}

Tahapan ini adalah tahapan dimana penulis melakukan testing atau pengujian website penjualan accessories handphone dan pengharum ruangan pada aplikasi peramban web (mozilla firefox dan google chrome). Jika terdapat kekuranganataupun terdapat kesalahan maka dapat dilakukan perbaikan dan kembali ke tahapan sebelumnya mulai dari analysis $\rightarrow$ test $\rightarrow$ code $\rightarrow$ design.

\section{Pair Programming}

Tahapan pair programming adalah tahapan dimana pembuat website bekerjasama dengan rekan atau team work nya, dalam hal ini penulis membuat website penjualan acessories handphone dan pengharum ruangan tidak dengan team sehingga pada tahapan ini hanya melakukan perbaikan melalui pembimbing, penulis menanyakan langsung apa yang harus diperbaiki dalam website yang penulis buat, sehingga ada komunikasi yang baik antara pembimbing dan penulis (mahasiswa).

\section{Collective Ownership}

Dalam tahapan ini penulis harus memahami baris kode program yang akan dibuat. Ketika akan membuat tabel admin maka ada ketentuan yang harus dilakukan berdasarkan isi field yang terdapat pada tabel admin. Jika dalam suatu team maka semua yang terlibat di dalam team harus memahami setiap kode program yang telah dibuat oleh penulis atau pembuat program.

\section{Coding Standards}

Tahapan ini adalah implementasi penulisan coding program. Dalam hal ini penulis melakukan penulisan program menggunakan bahasa pemrograman $p h p$.

\section{Continous Integration}

Tahapan continious integritas adalah tahapan dimana dosen pembimbing memberikan pendapat atau perbaikan untuk program penjualan accessories handphone dan pengharum ruangan yang dibuat, sehingga baik pemilik toko, pembimbing dan penulis terintegrasi dengan baik. 


\section{Sustainable Pace}

Tahapan ini merupakan tahapan waktu dimana setiap penulis harus menggunakan waktu yang tidak berlebihan sehingga akan menyebabkan kelelahan dan program yang dibuat terjadi kesalahan pada baris coding yang dibuat. Untuk itu penulis selalu menjaga kondisi badan terutama istirahat yang cukup.

\section{Customer Test}

Tahapan ini penulis menjalankan aplikasi program yang dibuat, tetapi dalam tahapan ini harus ada orang lain atau pembimbing, sehingga jika terdapat kesalahan maka dengan mudah akan langsung disampaikan dan diperbaiki.

\subsection{UML (Unified Modelling}

\section{Language)}

\subsubsection{Use Case Diagram}

Diagram use case menggambarkan interaksi antara use case dan actor dalam suatu sistem. Untuk mempermudah pemodelan, diagram use case untuk Sistem Informasi Penjualan Accessories Handphone dan Pengharum Ruangan Berbasis Web sebagai berikut :

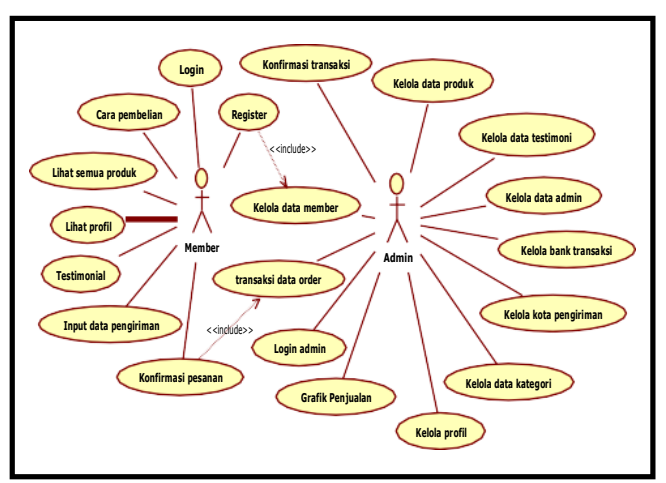

Gambar 3.5 Use Case diagram sistem informasi penjualan accessories

Handphone dan pengharum ruangan.

\subsection{Activity Diagram}

\subsubsection{Activity Diagram Login Calon}

\section{Pembeli/Admin}

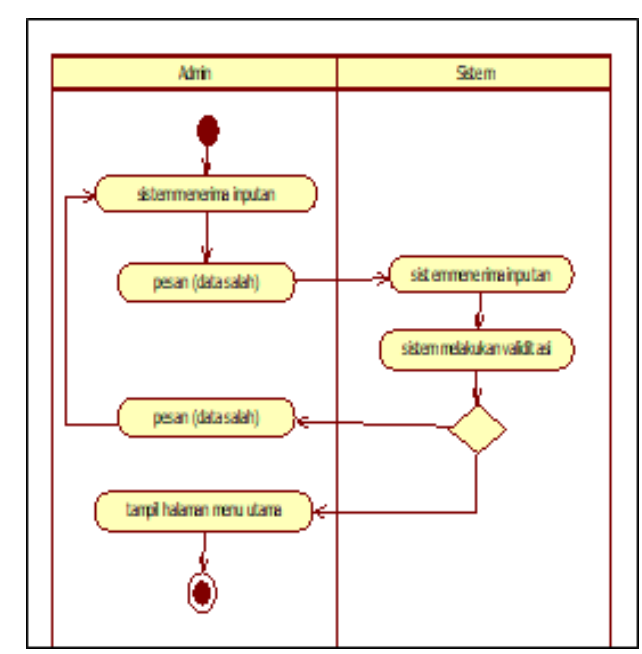

Gambar 3.6 Activity diagram login

calon pembeli atau admin

\subsubsection{Activity Diagram Kelola Data}

\section{Admin}

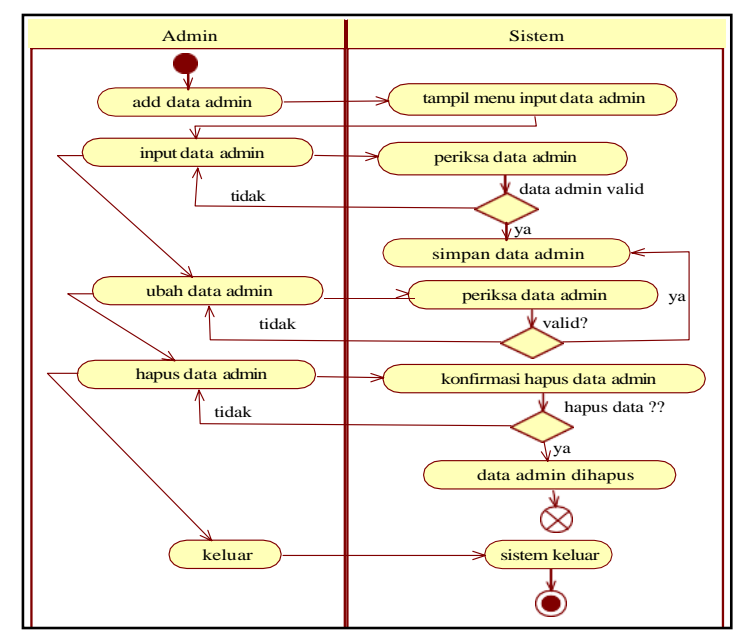


Gambar 3.7 Activity Diagram Kelola

Data Admin

\subsubsection{Activity Diagram Laporan}

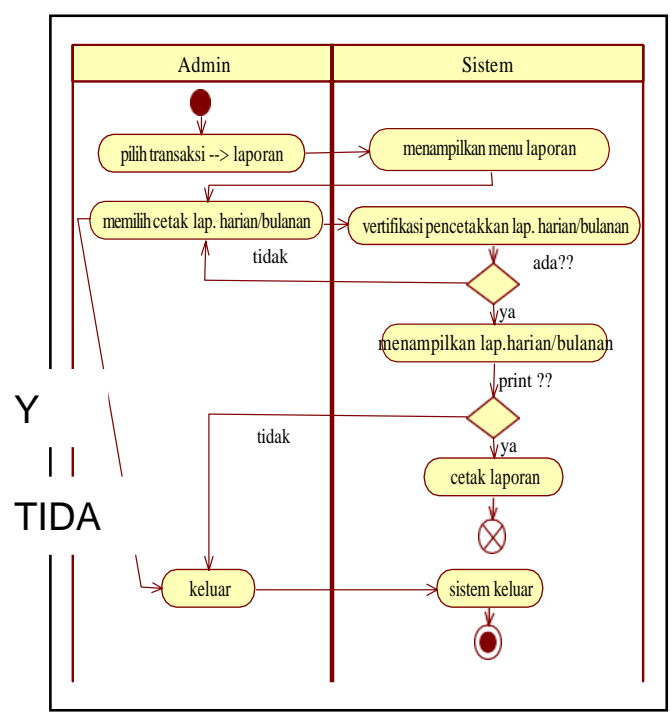

Gambar 3.8 Activity Diagram

\section{Pembuatan Class Diagram}

Class diagram mendeskripsikan jenisjenis objek dalam sistem dan berbagai macam hubungan statis yang terdapat di antara mereka. Class diagram mempunyai nama class, atribut, dan operasinya.

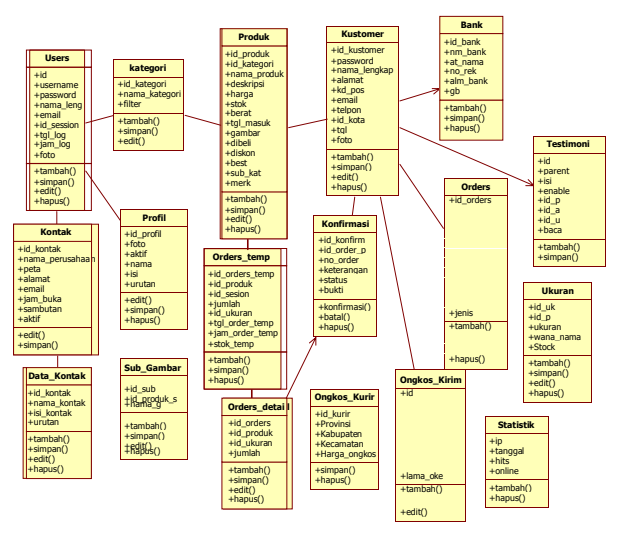

Gambar 3.9 Class Diagram sistem informasi penjualan acessories handphone dan pengharum ruangan berbasis web

\section{Hasil dan Pembahasan}

\subsection{Tampilan Login Petugas}

Pada waktu pertama kali User menjalankan program terlebih dahulu User harus Login sebagai petugas administrasi, Apabila halaman Login sudah terisi maka tinggal mengklik tombol Login. Apabila Password benar maka User akan masuk kedalam menu utama. Apabila salah maka tampilan layar belakang menjadi merah dan tidak bisa masuk ke menu utama.

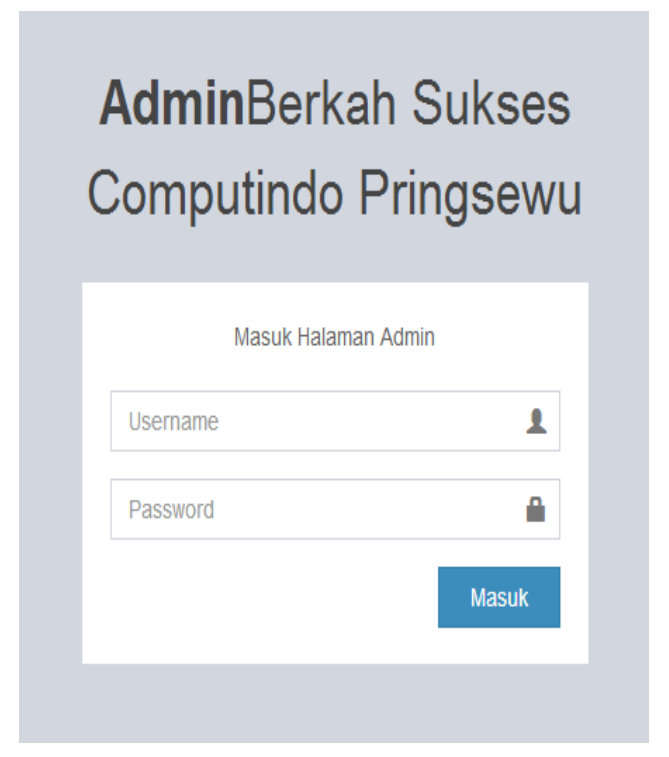

Gambar 4.1 Tampilan Halaman Login Petugas

\subsection{Tampilan Menu Utama}

Pada menu utama terdapat menu pilihan, profil, cara belanja, bukti resi 
JURnal InformASI dan KomPUTer

Volume 6 Nomor 1 2018

pengiriman, testimoni dan lokasi toko. Apabila $u$ ser ingin memulai berbelanja, maka tinggal mengklik produk yang ada kemudian mendaftar atau membuat akun di menu pendaftaran.

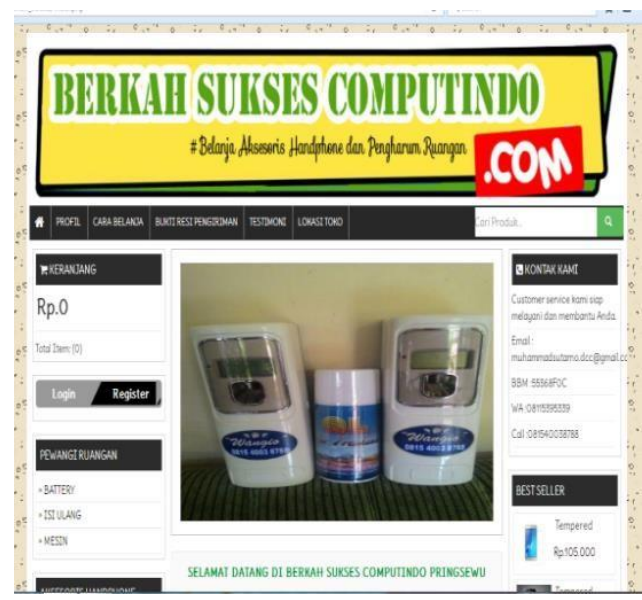

Gambar 4.2 Tampilan Menu Utama

\subsection{Tampilan Menu Profil}

Pada tampilan menu utama terdapat menu pilihan Profil yang berisi tentang profil perusahaan dari Berkah Sukses Computindo dengan tampilan sebagai

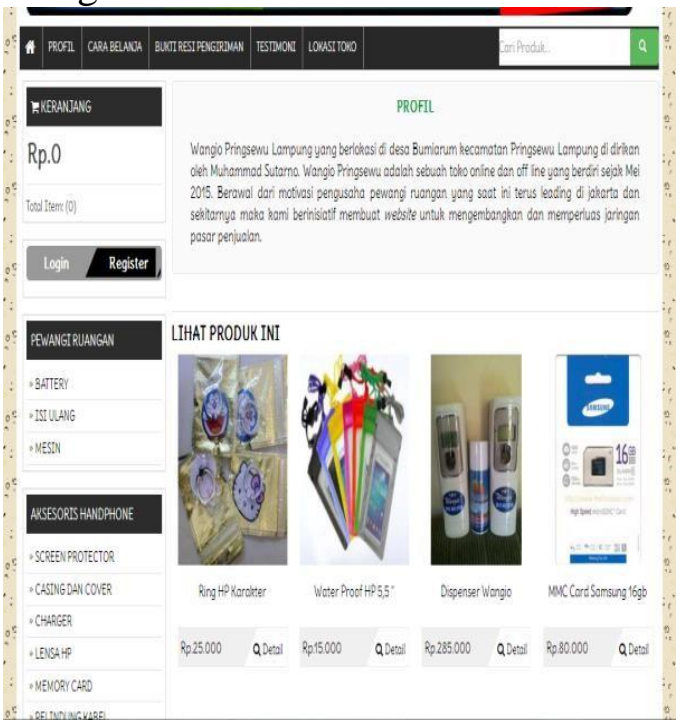

Gambar 4.3 Tampilan Menu Profil

\subsection{Tampilan Menu Cara \\ Berbelanja}

Pada tampilan menu utama terdapat menu menu pilihan cara berbelanja sebagai berikut:

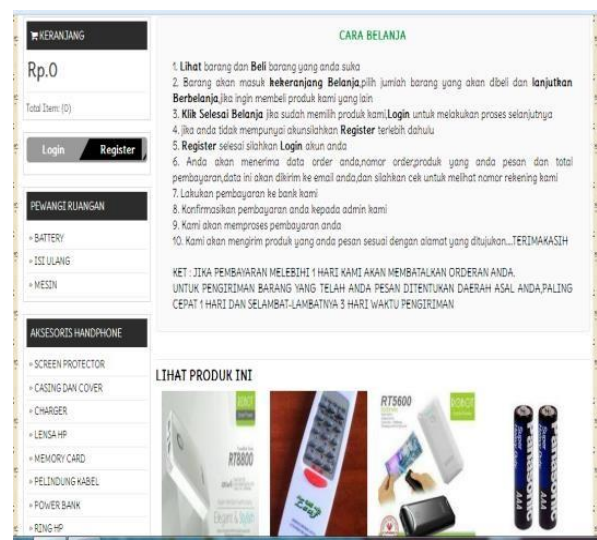

Gambar 4.4 Tampilan Menu Cara

Belanja

\subsection{Tampilan Menu Bukti Resi}

\section{Pengiriman}

Pada tampilan menu utama terdapat menu pilihan bukti resi pengiriman berdasakan waktu perbulan dengan tampilan sebagai berikut :

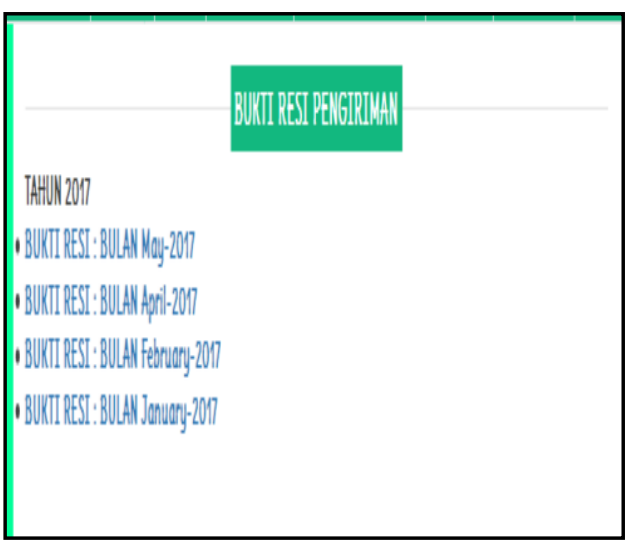


Gambar 4.5 Tampilan bukti resi

pengiriman

\subsection{Tampilan Menu Testimoni}

Pada tampilan menu utama terdapat menu pilihan testimoni dari member atau pembeli sebagai berikut :

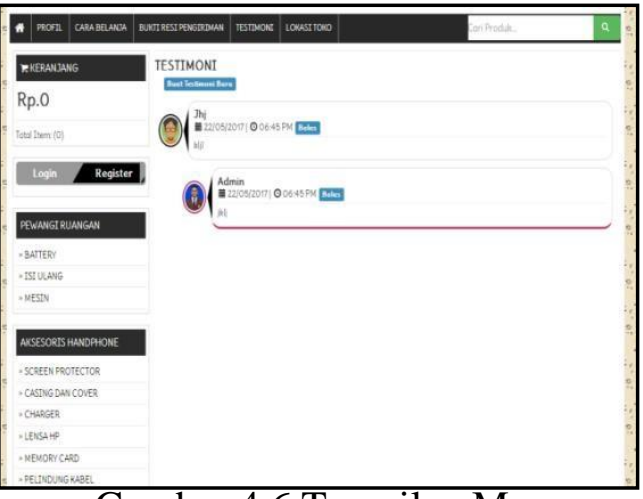

Gambar 4.6 Tampilan Menu

Testimoni

\subsection{Tampilan Menu Lokasi Toko}

Pada tampilan menu utama terdapat menu lokasi toko agar mempermudah konsumen dalam pencarian alamat toko dengan tampilan sebagai berikut

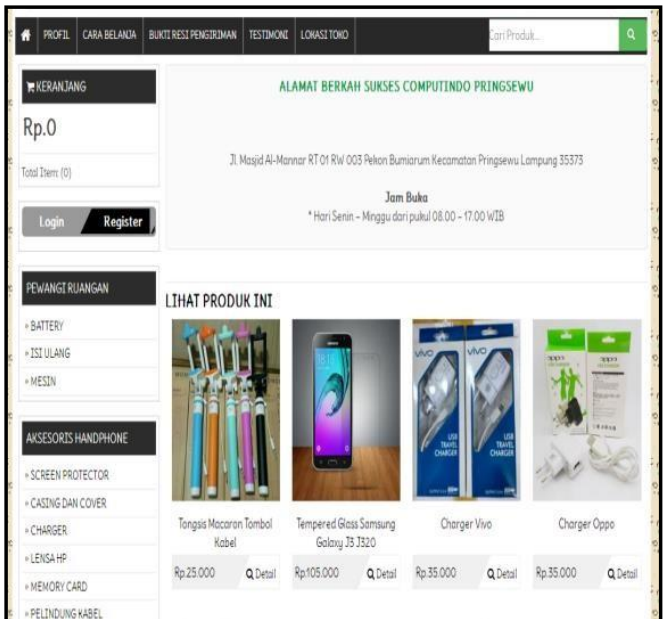

Gambar 4.7 Tampilan Menu Lokasi

Toko

\section{1 Kesimpulan}

Berdasarkan hasil analisa pada sistem informasi penjualan accessories handphone dan pengharum ruangan berbasis web pada toko Berkah Sukses Computindo, maka dapat disimpulkan beberapa hal yaitu :

1. Sistem informasi penjualan accessories handphone dan pengharum ruangan berbasis web pada toko Berkah Sukses Computindo dirancang untuk mempermudah petugas penjualan accessories handphone dan pengharum ruangan agar dalam melayani calon pembeli yang ingin mendaftar tidak memerlukan waktu yang lama lagi.

2. Untuk mempermudah membuat laporan data penjualan accessories handphone dan pengharum ruangan bagi petugas.

3. Untuk mempermudah calon pembeli dalam mencari informasi penjualan accessories handphone dan pengharum ruangan.

\subsection{Saran}

Dari hasil analisa pada sistem informasi penjulan accesories handphone dan pewangi rungan berbasis web pada toko Berkah Sukses Computindo ada beberapa saran diantaranya : 
1. Dibutuhkan sumber daya manusia yang menguasai komputer baik hardware dan software sehingga dalam mengoperasikan komputer bisa mendapatkan hasil yang optimal dan lebih baik lagi.

2. Untuk mengatasi permasalahan yang ada di petugas penjualan accessories handphone dan pengharum ruangan terutama dalam Sistem informasi penjualan acessories handphone dan pengharum ruangan berbasis web pada toko Berkah Sukses Computindo, maka diperlukan perubahan sistem yang berbasis website, dengan cara menggunakan suatu program aplikasi yang bisa mempercepat dan mempermudah pekerjaan yang ada.

3. Untuk meningkatkan suatu pengolahan database, maka disarankan untuk mengubah proses manual menjadi otomatis secara komputerisasi.

4. Untuk menjaga suatu keamanan database yang ada maka disarankan agar membuat database tersendiri untuk password yang akan dijalankan oleh operator petugas penjualan accessories handphone dan pengharum ruangan.

\section{Daftar Pustaka}

[1]. Bimo Sunarfrihantono, $P H P$ dan MySQL untuk Web, Yogyakarta.

[2]. Ferdiana, Ridi. Rekayasa Perangkat Lunak yang Dinamis dengan Global Extreme

Programming.

Yogyakarta: Penerbit ANDI, 2012.

[3]. Ferdiana, Ridi, Lukito Edi Nugroho, Paulus Insap Santoso, dan Ahmad Ashari. "Process Framework in Global Extreme Programming." Computer Science and Information Security, 2010.

[4]. HM Jogiyanto, Analisis dan Desain Sistem Informasi : pendekatan terstruktur teori dan praktek aplikasi bisnis, andi offset, yogyakarta, 2010.

[5]. http://www.tutorialkamp us.com/2014/06/sistemperancangan-aplikasitoko-baju_12.html?m=1

[6]. M.Safii.2004.

Membangun Aplikasi Berbasis PHP dan MySQL, Andi. Yogyakarta.

[7]. Nugroho, Bunafit, Aplikasi Pemrograman WEB Dinamis Dengan PHP dan MySQL, Gava Media Komputindo, Jakarta.

[8]. Tim Penyusun, Kamus Besar Bahasa Indonesia, Balai Pustaka, Jakarta 2007

[9]. Sri Dharwiyanti, Romia Satria Wahyono, Pengantar Unified 
JURnal InformASI dan KomPUTer

Volume 6 Nomor 1

2018

Modelling Language

(UML),

http://www.ilmukomput

er.com,27 Juli 2009.

[10]. Widhiartha, putu.(2008).

Extreme Programming melakukan

pengembangan

perangkat lunak lebih

sederhana.

http://www.ilmukomput

er.com 